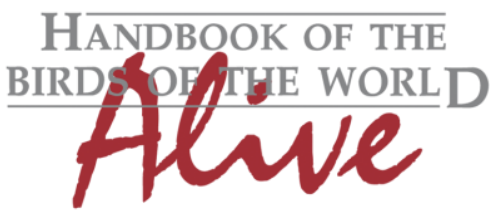

\title{
ORNITHOLOGICAL NOTES
}

\section{Notes on the vocalizations of Black-eared Hemispingus (Hemispingus melanotis)}

\section{Peter Boesman}

In the following we briefly analyze and compare voice of the different races of Black-eared Hemispingus (Hemispingus melanotis). We also try to quantify the extent of any vocal differences using the criteria proposed by Tobias et al. (2010), as a support for taxonomic review. We have made use of sound recordings available on-line from Xeno Canto (XC) and Macaulay Library (ML).

A comparison of voice per race, illustrated with sonograms: melanotis

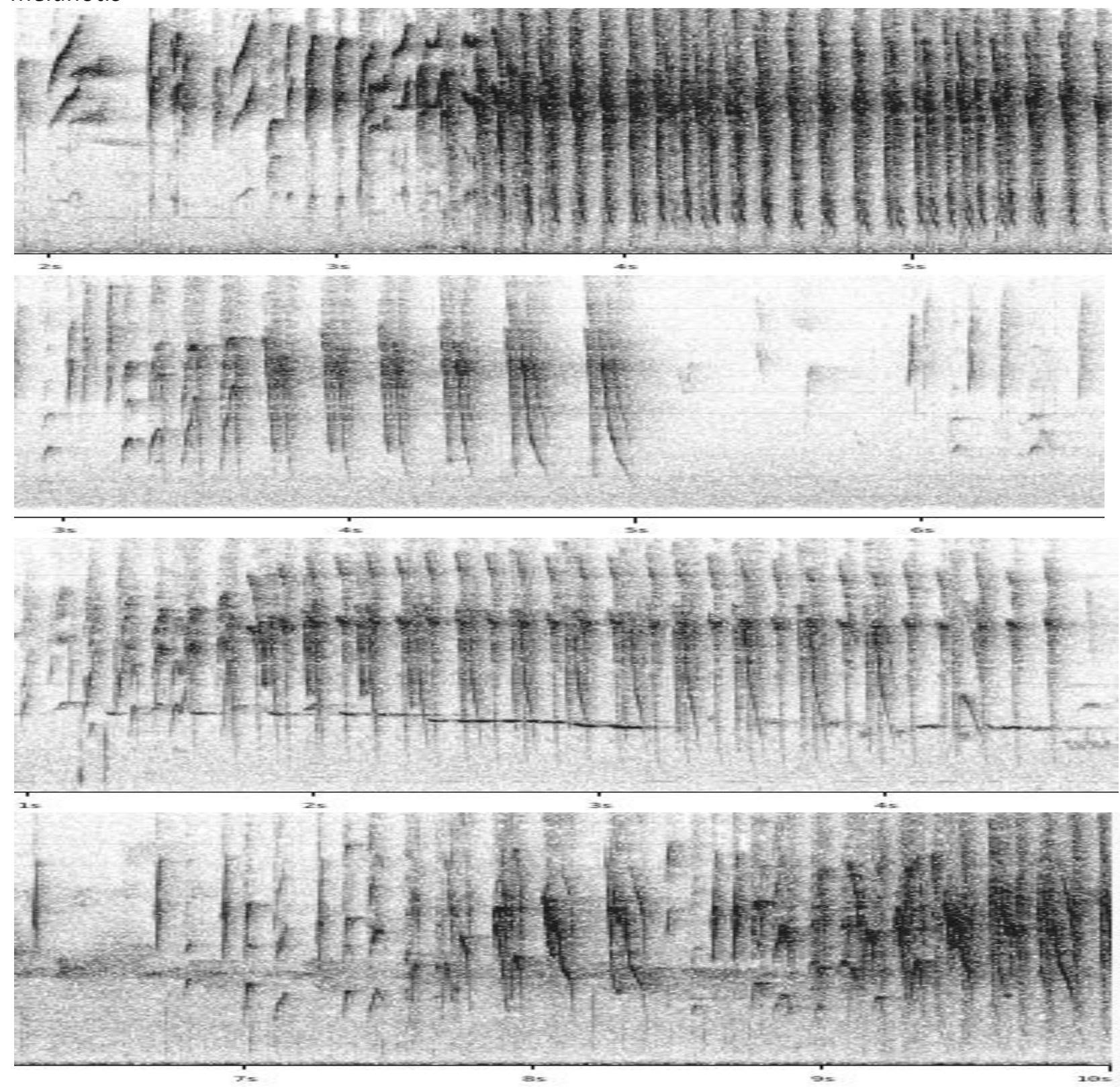




\section{HANDBOOK OF THE \\ Alve \\ ORNITHOLOGICAL NOTES}

\section{berlepschi}
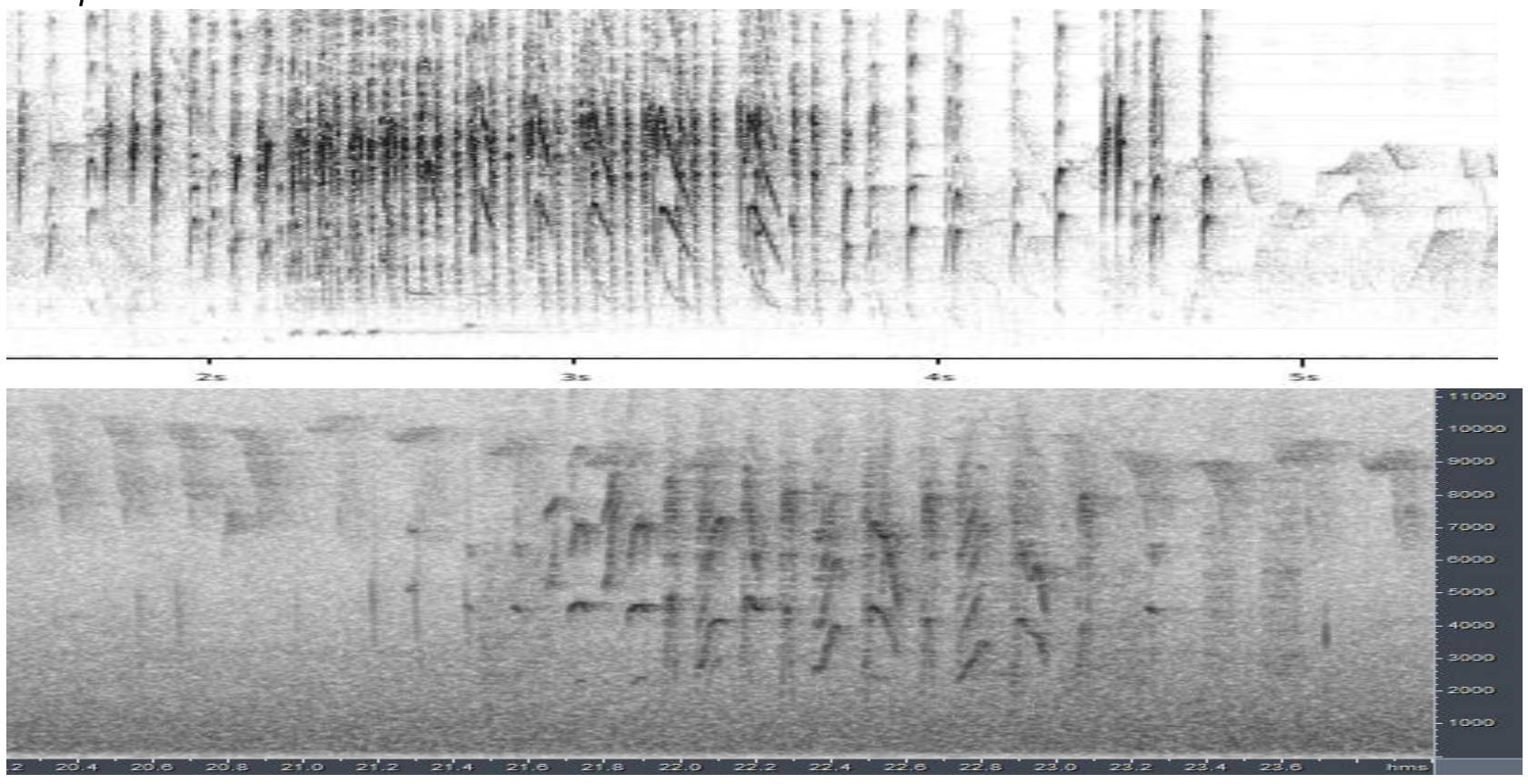

castaneicollis

Bolivia
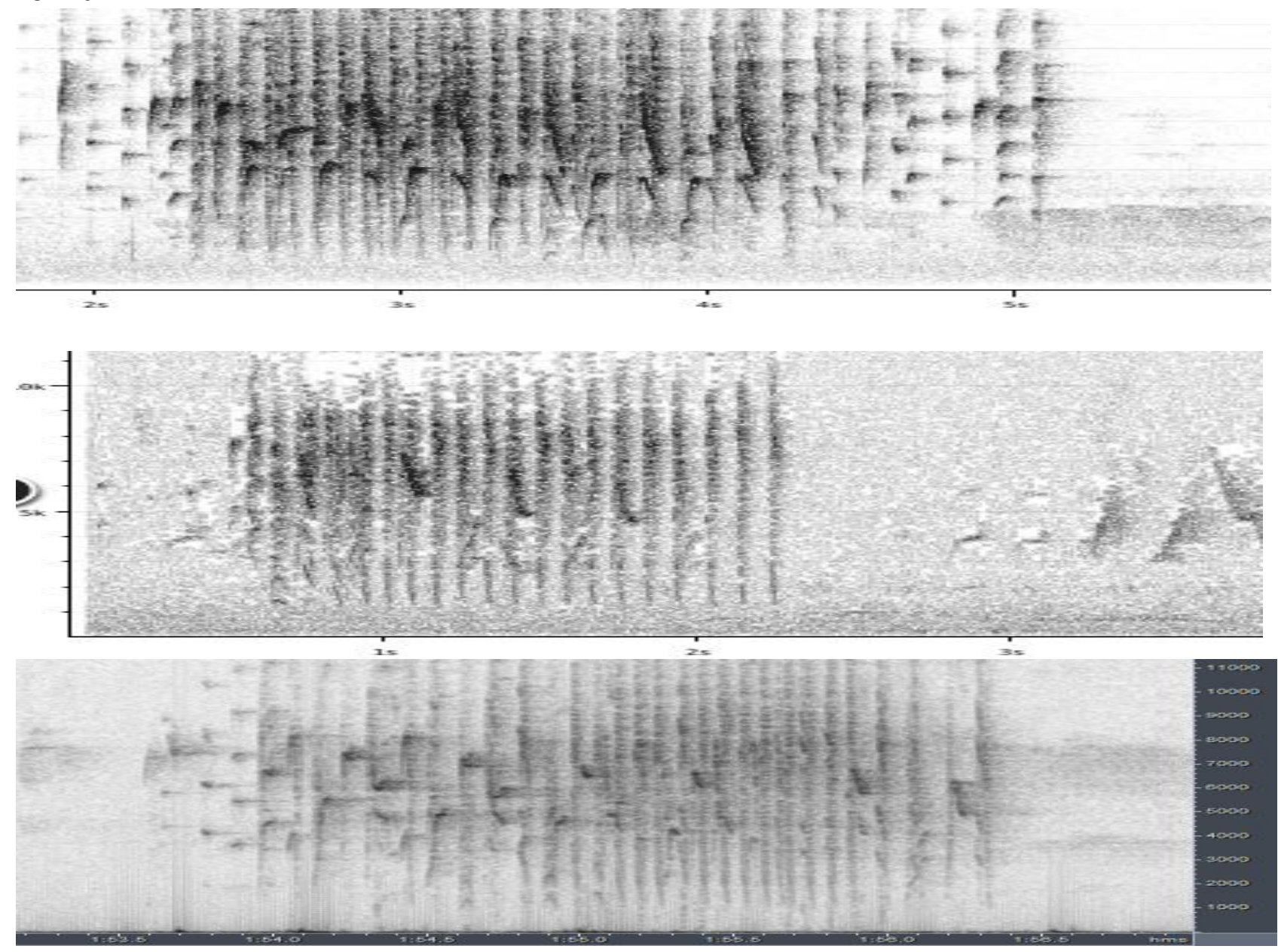

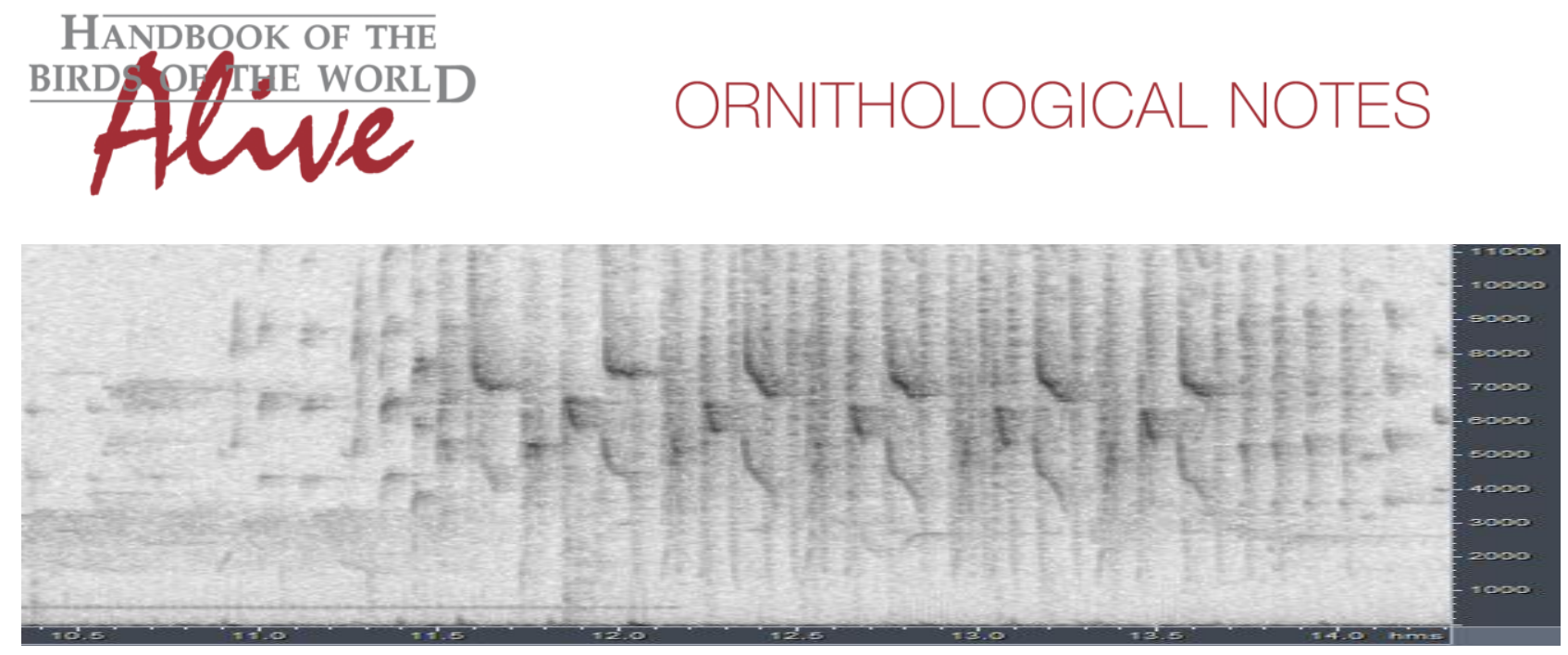

Most commonly-uttered song-like vocalization is a complex chattering of two (or more?) birds. From the above examples, it would seem that this song of nominate starts with intro notes (upslurred) and bursts into a chatter which consists of fast repeated (nearly) identical notes. These notes seem to be the combination of a very sharp downslurred note and a more gently downslurred note (with some variation, but typically dropping down from 8$9 \mathrm{kHz}$ to $1-2 \mathrm{kHz}$, freq. range c. $6-7 \mathrm{kHz})$.

berlepschi and castaneicollis seem to have a different song pattern compared to nominate. Song starts with intro notes (some upslurred and others short overslurred, proportionally rather the opposite of nominate) and the chatter seems to lack the steep downslurred notes, rather lower-pitched less downslurred notes (frequency range much smaller, c. $2-3 \mathrm{kHz}$ ) with harmonics.

While there is quite some variation in song (possibly also influenced by the number of birds involved in the chattering), the above-mentioned differences seem to be quite diagnostic. Quantification of this vocal difference could be done as follows:

Nominate has steeply downslurred notes with much larger freq. range than other races (score 2), different note shapes (1) and a different assembly of introductory notes (score 1 ). Total vocal score about 3.

This note was finalized on 4th July 2016, using sound recordings available on-line at that moment. We would like to thank in particular the sound recordists who placed their recordings for this species on XC and ML: Nick Athanas, Peter Boesman, Oswaldo Cortes, Thomas Donegan, David Geale, Bennett Hennessey, Sebastian Herzog, Dan Lane, Mitch Lysinger, Gabriel Leite, Bernabe Lopez-Lanus, Oscar Marin-Gomez, John V Moore, Jonas Nilsson, Ted Parker, Heinz Remold, Mark Robbins, Andrew Spencer and Sam Woods.

\section{References}

Tobias, J.A., Seddon, N., Spottiswoode, C.N., Pilgrim, J.D., Fishpool, L.D.C. \& Collar, N.J. (2010). Quantitative criteria for species delimitation. Ibis 152(4): 724-746. 


\section{Recommended citation}

Boesman, P. (2016). Notes on the vocalizations of Black-eared Hemispingus (Hemispingus melanotis). HBW Alive Ornithological Note 398. In: Handbook of the Birds of the World Alive. Lynx Edicions, Barcelona. (retrieved from http://www.hbw.com/node/1253792 on 2 December 2016). 